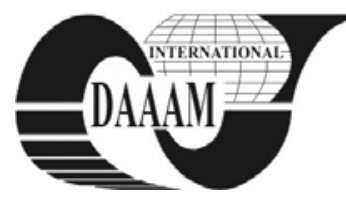

Annals of DAAAM for 2011 \& Proceedings of the 22nd International DAAAM Symposium, Volume 22, No. 1, ISSN 1726-9679 ISBN 978-3-901509-83-4, Editor B. Katalinic, Published by DAAAM International, Vienna, Austria, EU, 2011 Make Harmony between Technology and Nature, and Your Mind will Fly Free as a Bird

\title{
OPTICAL PROPERTIES OF TEO2 PBCL2 PBF2 GLASSES DOPED WITH PR AND ER
}

\section{LABAS, V[ladimir]; MINARIK, S[tanislav]; TRNOVCOVA, V[iera] \& PSOTA, J[ozef]}

\begin{abstract}
Influence of crucibles (Au or Pt) on the structure and optical properties of $60 \mathrm{TeO}_{2} \cdot 40 \mathrm{PbCl}_{2}$ and $60 \mathrm{TeO} \cdot 20 \mathrm{PbCl}_{2} .20 \mathrm{PbF}_{2}$ glasses, "pure" and doped with 1000 wt-ppm $\mathrm{Pr}^{3+}$ or $\mathrm{Er}^{3+}$, which are added as metals, chlorides, or oxides, is reported. In glasses prepared in Au crucibles, the absorption edge is shifted to shorter wavelengths and the color of the glass is changed from red to yellowish, respectively. In the range of 640-700 $\mathrm{nm}$, five Pr or six Er photoluminescence $(P L)$ peaks are observed. In the range of $200-1200 \mathrm{~cm}^{-1}$, Raman scattering (RS) spectrums show 6 (for Pr doping) or 7 (for Er doping) bands. On basis of RS spectrums, shortdistance ordering of glasses is discussed.
\end{abstract}

Key words: glass, photoluminescence, raman scattering

\section{INTRODUCTION}

Tellurite glasses are characterized by a wide transmission range $(\approx 400 \mathrm{~nm}-6 \mu \mathrm{m})$, low phonon energy $\left(\leq 800 \mathrm{~cm}^{-1}\right)$, high density $\left(\approx 5.5 \mathrm{~g} / \mathrm{cm}^{3}\right)$, and high refractive index $(\approx 2)$.Good thermal and mechanical properties enable fiber production. This paper presents 1/ Raman scattering, optical absorption, and photo-luminescence of $60 \mathrm{TeO}_{2} \cdot 40 \mathrm{PbCl}_{2} \quad(6 \mathrm{~T} 4 \mathrm{P})$ and $60 \mathrm{TeO}_{2} .20 \mathrm{PbCl}_{2} \cdot 20 \mathrm{PbF}_{2}(6 \mathrm{~T} 2 \mathrm{P} 2 \mathrm{P})$ glasses, prepared in $\mathrm{Pt}$ or Au crucible sand doped with 1000 wt-ppm $\mathrm{Pr}^{3+}$ or $\mathrm{Er}^{3+}$ in various chemical forms, and 2/ influence of crucibles on the microstructure and optical properties of the glasses. Electrical properties and structure are interesting too (Bošák 2007, Kubliha 2009).

\section{EXPERIMENTAL DETAILS}

Glasses are melted in Pt or Au crucibles at $720{ }^{\circ} \mathrm{C}$, for 30 min. 1000 wt-ppm of Er or Pr in the form of metal, oxide or chloride are added (O’Donnell 2003, Popescu 2007, Trnovcová 2007). Upon preparation in Pt and Au crucibles, glasses are red or yellowish, respectively. Absorption, photoluminescence (PL) and Raman scattering (RS) spectra are measured at RT. For absorption measurements, (200-3000 nm), deuterium discharge tube as a source is used. For PL (450-700 nm) and RS (150$3000 \mathrm{~cm}^{-1}$ ) measurements, He-Ne laser $(632.8 \mathrm{~nm})$ is used.

\section{RESULTS AND DISCUSSION}

In 6T4P glasses prepared in Pt crucibles, an absorption band on the absorption edge is observed (Fig. 1A). It is assigned to Pt colloids. In T6P2P2 glasses prepared in $\mathrm{Pt}$ crucibles, we observe another band resulting from their interaction with fluorine. Upon doping, the edge gets steeper. In glasses prepared in Au crucibles, 1/ the edge is shifted to a shorter wavelength, $2 /$ the color of glasses is changed, $3 /$ doping has a negligible influence on the absorption edge, and 4/ no absorption band on the absorption edge is observed.

In the range of $640-690 \mathrm{~nm}$, five PL bands, at $645.3,652.4$, 659.3, 659, and 663.3nm, are observed both in "pure" and Prdoped 6T4P glasses (Fig.1B). They are attributed to ${ }^{3} \mathrm{P}_{1} \rightarrow{ }^{3} \mathrm{~F}_{2}$,
${ }^{3} \mathrm{P}_{0} \rightarrow{ }^{3} \mathrm{~F}_{2},{ }^{3} \mathrm{P}_{1} \rightarrow{ }^{3} \mathrm{~F}_{3},{ }^{3} \mathrm{P}_{0} \rightarrow{ }^{3} \mathrm{~F}_{4}$, and ${ }^{3} \mathrm{P}_{1} \rightarrow{ }^{3} \mathrm{~F}_{4}$ transitions in $\mathrm{Pr}^{3+}$ ions.
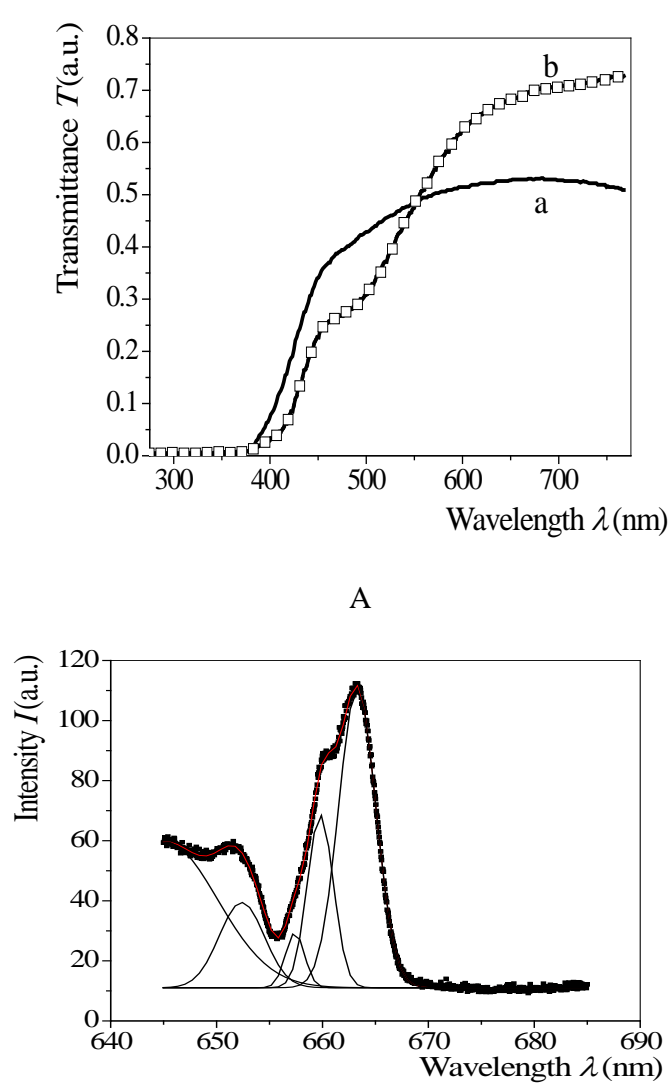

B

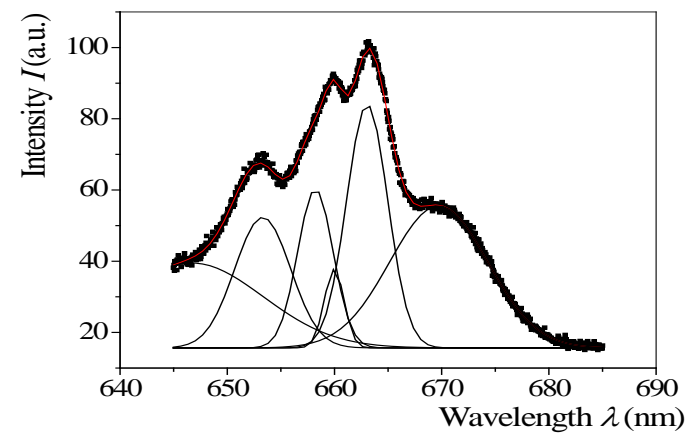

C

Fig.1. A/ Absorption edges of "pure"6T4P glasses prepared in a/ Au and b/ Pt crucibles; B/ deconvoluted PL spectrum of 6T4P glass prepared in Au crucible, doped with 1000 wt-ppm Pr; C/ deconvoluted PL spectrum of 6T4P glass, prepared in Pt crucibles, doped with 1000 wt-ppm $\mathrm{Er}_{2} \mathrm{O}_{3}$ 


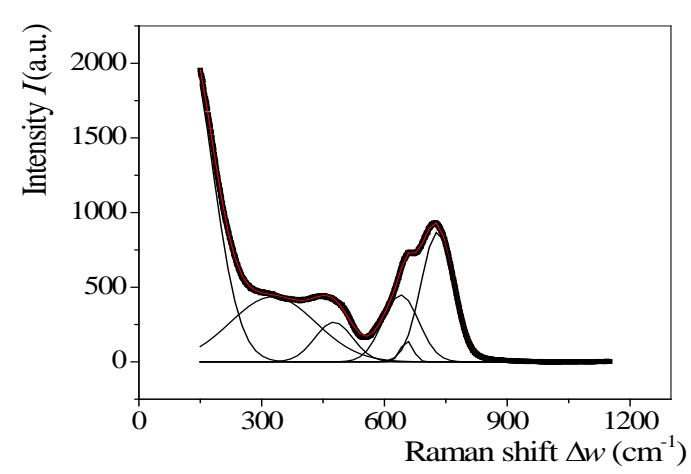

A

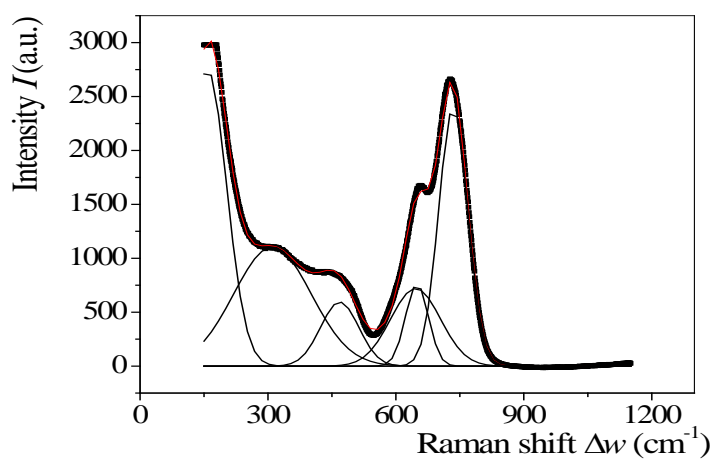

B

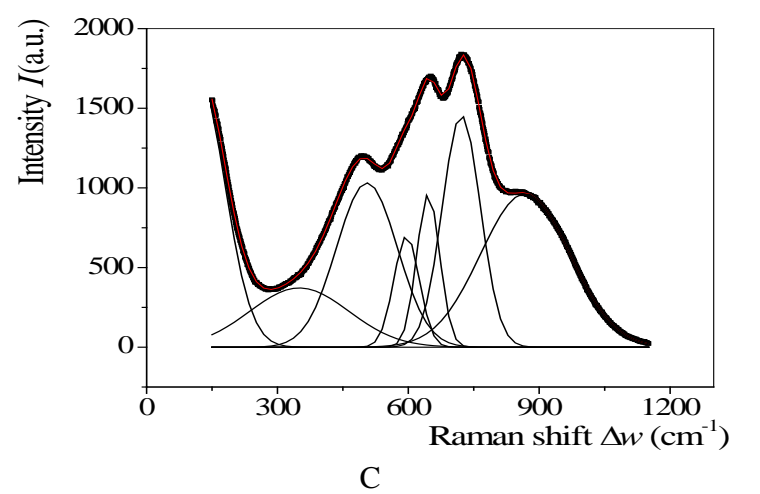

Fig. 2. Deconvoluted RS spectra of 6T4P glasses A/ doped with metallic Pr; prepared in Au crucible, B/ doped with $\mathrm{PrCl}_{3}$, prepared in Pt crucible, and C/ of 6T2P2P glass, prepared in $\mathrm{Pt}$ crucible, doped with $\mathrm{Er}_{2} \mathrm{O}_{3}$ (Kubliha, M., Trnovcová, V., 2009)

Traces of $\mathrm{Pr}^{3+}$ ions are present also in "pure" 6T4P glasses. Six PL peaks, at 648, 652.9, 659, 660, 663.2, and $669 \mathrm{~nm}$, are observed in "pure" and Er-doped 6T2P2P glasses and in Erdoped 6T4P glasses (Fig. 1C). They are attributed to ${ }^{4} \mathrm{~F}_{9 / 2} \rightarrow{ }^{4} \mathrm{I}_{15 / 2}$ transitions. "Pure" 6T2P2P glasses contain traces of $\mathrm{Er}^{3+}$ ions.

Relative intensities of PL bands depend on the chemical form of dopants and on the crucible. Positions of these bands are almost independent of the concentration and chemical form of dopants, material of the crucible, and glass composition.

In the range of $200-1200 \mathrm{~cm}^{-1}$, in 6T4P glasses, both "pure" and doped with Pr, prepared in Au or Pt crucibles, six RS peaks, at $122,323,474,643,656$, and $732 \mathrm{~cm}^{-1}$, are observed (Figs. 2A,B). In 6T4P glasses doped with Er and in 6T2P2P glasses, both "pure" and doped with Er, prepared in Pt crucibles, seven RS peaks, at 95, 323, 494, 598, 647,727, and $862 \mathrm{~cm}^{-1}$, are observed (Fig. 2C). Relative intensities of RS peaks depend on the chemical form of dopants and on the material of the crucible. Positions of these bands are independent of the concentration and chemical form of dopants, and of the material of the crucible. There is a pronounced difference between RS spectrums of Pr-doped and Er-doped glasses.

Basic structural units in tellurite glasses are asymmetrical $\left[\mathrm{TeO}_{4}\right]$ trigonalbipyramids (tbp) with lone pair electrons. Adding modifiers, the coordination state of Te changes, from $\mathrm{TeO}_{4}$ tbp through an intermediary $\left[\mathrm{TeO}_{3+1}\right]$ polyhedron to a $\left[\mathrm{TeO}_{3}\right]$ trigonal pyramid (tp), and the concentration of nonbridging oxygen increases. Peaks at $732 \pm 5 \mathrm{~cm}^{-1}$ and $652 \pm 5 \mathrm{~cm}^{-1}$ are attributed to stretching vibrations of tp and tbp, respectively. The peak at $645 \mathrm{~cm}^{-1}$ comes from $\mathrm{TeO}_{3+1}$ polyhedrons. The peak near $480 \mathrm{~cm}^{-1}$ corresponds to bending or stretching vibrations of Te-O-Te linkages of vertex-sharing tbp units. Its intensity can be considered a measure of the network connectivity. $\mathrm{Pb}^{2+}$ enters the glass as an intermediate, increases the number of non-bridging oxygens and decreases the coordination number of Te.

Peak at $862 \mathrm{~cm}^{-1}$ comes probably from $\mathrm{Pb}-\mathrm{O}, \mathrm{Cl}-\mathrm{Pb}-\mathrm{Cl}$ or $\mathrm{F}-\mathrm{Pb}-\mathrm{F}$ stretching vibrations. However, it is not clear why these vibrations are supported by Er. Low frequency peaks are assigned to rotational and torsional modes of Te-O-Te linkages.

In glasses prepared in gold crucibles, the peak at $468 \mathrm{~cm}^{-1}$ is more pronounced than that in glasses doped with Er. It indicates a better connectivity of the glass network in these glasses. Also the intensity ratio of tbp $\left(654 \mathrm{~cm}^{-1}\right)$ and tp (735 $\mathrm{cm}^{-1}$ ) peaks is significantly larger, in these glasses. The intensity ratio of both peaks determines the ratio of tbp and tp structural units. It seems that the presence of Er increases the number of $\mathrm{TeO}_{3}$ structural units and decreases the number of Te-O-Te linkages (O’Donnell 2003).

\section{ACKNOWLEDGEMENTS}

This work was supported by the Slovak National Science Foundation under grants VEGA No.1/0645/10 and KEGA 327010STU-4/2010

\section{REFERENCES}

Bošák, O., Kalužný, J.,Kubliha, M., Sorentínyová, Z., Pret’o, J., Vacval, J., Hronkovič, J. (2007): The possibilitty of investigation vulcanisation and degradation a rubber blends using the measurents of electrical and dielectrical parameters. Materials Engineering. Materiálové , ISSN 1335-0803

Bošák, O., Kalužný, J., Preto, J., Vacval, J., Kubliha, M., Hronkovič, J. (2007): Electrical properties of a rubber blend used in the tyre industry. Polymers for Advanced Technologies. - ISSN 1042-7147. - 18

Kubliha, M., Trnovcová, V., Furár, I., Kadlečíková, M., Pedlíková, J. Greguš, J., J. Non-Cryst. Solids,355, 20352039(2009)

Kubliha, M., Investigating structural changes and defects of non-metallic materials via electrical methods. - 1 st ed. Dresden : Forschungszentrum Dresden - Rossendorf, 2009.

O’Donnell M.D., Miller C.A., Furniss, D., Tikhomirov, V.K., Seddon, A.B. J. Non-Cryst. Solids,331,48(2003)

Popescu, M, Kubliha, M., Kalužný, J., Velea, A., Loerinczi, A. (2007): DC conductivity in $\mathrm{GeSb}_{2} \mathrm{Te}_{4}$ and $\left(\mathrm{GeSb}_{2} \mathrm{Te}_{4}\right)_{(90)}\left(\mathrm{SnSe}_{2}\right)_{(10)}$ phase change materials. Journal of Optoelectronics and Advanced Materials. - ISSN 14544164. - Vol. 9, Iss. 12 (2007), s. 3951-3953

Trnovcová, V. , Furár, I., Kadlečíková, M., Greguš, J., Pedlíková, J., Ožvoldová, M., Bošák, O., J. Optoelectr. Advanced Mater., 9, 3223 (2007) 